\title{
Negotiating 'Normal': the Management of Feminine Identities in Rural Britain
}

\author{
by Fiona Gill \\ University of Sydney \\ Sociological Research Online, Volume 12, Issue 1, \\ $<$ http://unw. socresonline.org.uk/12/1/gill.html> \\ doi:10.5153/sro. 1339
}

Received: 26 Jan 2006 Accepted: 21 Nov 2006 Published: 31 Jan 2007

\begin{abstract}
This paper examines the management of feminine identities in a women's rugby team in a rural British community. In so doing, the issue of new, and potentially problematic, forms of femininity are explored, with their attendant social consequences. The team, known as the Jesters, is situated in a social context which is dominantly masculine and heterosexist, with rigidly enforced gender roles. Due to their participation in rugby, a 'man's game', the Jesters are threatened with marginalisation for their apparent failure to conform to, and potential disruption of, established gender norms. This threat is managed through the performance of certain 'inauthentic' feminine identities (hyper-femininity and heterosexuality) on the part of the entire team. It is this 'team identity' which lies at the heart of this paper.
\end{abstract}

This paper therefore examines the group dynamics of identity performance and negotiation. In negotiating 'normal' the Jesters are forced to confront changing gender norms and social contexts within the team itself. This paper also examines the difficulties faced by individuals when their own interests are opposed to the interests of the group of which they are a part. Although largely uncaring about the private lives of team members, the heterosexual members of the Jesters refuse to tolerate the performance of alternative versions of femininity when it may result in the exclusion of the team as a whole. This paper therefore examines the differing interests of heterosexual and lesbian femininities within a potentially marginalised group and some of the coping mechanisms adopted by both groups to develop a coherent team image.

\section{Keywords: Normal, Identity, Gender, Sexuality, Performance}

\section{Introduction}

1.1The development and performance of social norms are important aspects of social interaction. This paper examines the ways in which gender norms are negotiated in a context where they are problematised by the behaviour of a group of women. As such, this paper examines the negotiation of feminine identities in a women's rugby team located in a rural British community. In particular, it examines the ways in which 'normal' is established within the team and how 'normality' is understood in relation to external conceptions of normal or appropriate behaviour. The team, known as the Jesters, are located in Bordertown, a community characterised by hetero-normativity and a masculine public life. As such, the Jesters represent a threat to established gender norms and are forced to negotiate a 'new' or acceptable type of normality as part of the team's public face, as well as their private interactions.

1.2As participants in a man's game, the Jesters must perform an acceptable version of a rugby playing identity. That is, they must master the physical and cultural aspects of being a rugby player in order to gain the acceptance and respect of the male members of their club. This is necessary in order to access playing, training and social facilities maintained by Bordertown Rugby Club. Such a performance undermines their gender identity, resulting in their characterisation as masculine and, within the context of Bordertown, lesbian ${ }^{[1]}$. This paper will explore the implication of such a characterisation, arguing that it results in an atmosphere of compulsory heterosexuality within the team. The Jesters have well established strategies and rituals to manage this stigmatisation, but they result in the marginalisation of several team mates. Finally, this paper will examine the situation of these team-mates, arguing that they form an important group of scape-goats for the rest of the Jesters. Being able to point the finger at a small group of 'abnormal' women enables the bulk of the Jesters to achieve social acceptance. This strategy comes at a high price for those Jesters sacrificed. 
Jesters as a full member for two and a half seasons, playing and training with the team while carrying out participant-observation and interviews. In all, seven team members were interviewed, in addition to interviews with seven male club members. This data was supplemented by earlier research carried out on the local community identity, using interviews with members of three local football teams. In this way, I was able to develop a strong sense of both Bordertown's context in relation to women outside a support network such as the Jesters, and also within it. I was also able to experience first hand the sometimes fraught identity negotiations caused by involvement in a highly problematic activity. These experiences have informed my analysis, and assisted in the development of interview guides. All interviews were unstructured, particularly with team-mates who related to me as a friend rather than an 'outsider'. This enabled me to ask questions about issues which were both personal and subjective. All respondents were anonymised with identifying characteristics removed from their data. Information deemed too sensitive was omitted.

1.4 None of the players interviewed were identified as lesbian at the time of the research. It became clear to me that I was walking a very fine line between inclusion and exclusion (Gill and Maclean 2002: 2.11-12.12). It became clear that interviewing team members perceived as 'abnormal' would jeopardise my own place on the team, and thus the entire project. I made the decision, therefore, to interview only those members who were not lesbian. This is still an uncomfortable decision to have made, flying against the feminist and inclusive principles upon which I was working. It meant, however, that the data I collected was in the form of participant-observation as I strove to balance what I felt was ethically and morally acceptable, and what was realistically possible given my own circumstances.

\section{Performing 'normal': the construction of deviance and social exclusion}

2.1 The construction of normal is one of the on-going boundary-drawing activities which enable the smooth flow of social life. Defining normality codifies the abnormal and the socially unacceptable, reinforcing routinised and collectivised behaviours and discourses (Jenkins 1999: 166). Thus, Hacking argues that

The normal stands indifferently for what is typical, the unenthusiastic objective average, but it also stands for what has been, good health, and for what shall be our chosen destiny. This is why the benign and sterile-sounding word 'normal' has become one of the most powerful ideological tools of the twentieth century. (Hacking 1990: 169)

2.2 Normality therefore stands for continuity, the unexceptional and the unthreatening. It also represents something which works for particular groups and communities, meaning that the abnormal represents the strange, threatening and uncertain. The abnormal also threatens to unsettle existing patterns of behaviour and power structures. Both categories are temporally bound, and subject to change. The power of normality, however, lies in its apparent timelessness. For these reasons the abnormal and deviant are subject to social censure.

2.3 Gender norms tend to be strictly policed. In particular, the appropriate performance of gender, and specifically appropriate femininities, is enforced (Butler 1997: 405). Although sport is one of the main contexts in which this occurs. Sport plays a significant role in the development and expression of gender identities as an arena where opportunities exist for the empowerment and redefinition of identities (Cahn 1994; Hargreaves 1994; Caudwell 1999), it also reinforces existing gender norms and definitions of masculinity and femininity. This dual nature is shown in the debates surrounding the movement of women into traditionally 'male' sports such as football and weightlifting, and the corresponding impact on conceptions of 'femininity'. This paper shows that the team's conceptions and performances of 'femininity' are conventional and heterosexual, with rigid internal control over team members in terms of sexual and gender identity despite 'unfeminine' public performances.

2.4 Links between sport and gender performance have been well documented (Sabo 1990; Segal 1990; Kane and Disch 1993; Klein 1993; Mansfield 1993; Russell 1997; Caudwell 1999; Hill 1999; Irwin 2001). Women involved in 'men's sports' are excluded from facilities, attacked socially through slurs on their femininity and sexuality, and rewarded for their performance of an acceptable version of femininity or female sexuality. This is illustrated in the atmosphere of 'compulsory heterosexuality' in which many female sports teams operate (Lenskyj 1994: 363; Kolnes 1995: 61). Female athletes are expected to conform to norms of heterosexual attractiveness, regardless of their own sexual orientation. This is achieved by attention to their appearance (Cox and Thompson 2000: 14) and their apparent sexual availability to men. Labelling female athletes as 'lesbian' represents a strategy to maintain existing gender norms by marginalizing women who fail to conform (Caudwell, 1999: 391; Hargreaves, 1994: 261; Butler 1990: 19). As this research shows, in the context of Bordertown, lesbianism has been used both to scare women away from sport and to control the behaviour of those women in it. Situated in a small community which seems to be characterised by rigid gender norms and the relative homogeneity of social norms and behaviours, the Jesters exist outside these norms of behaviour, and as such, attract more censure than might have been the case in larger 
towns.

\section{'You're not women; you're rugby players!': gender and rugby}

3.1 Playing rugby involves the Jesters in a masculine context. With its emphasis on controlled violence, physicality and self-sacrifice for the good of the team, rugby in Britain and some British colonies has come to epitomise the characteristics of appropriate masculinity (Chandler 1996: 27; Morrell 1996: 91; Vincent 1998: 124; Dunning 1999: 63; Maclean 2000: 257). This involves the establishment of the identity of 'rugby player' in terms of behaviour on and off the pitch. This identity is a performance which runs contrary to established gender norms. That is women can either be rugby players, or they can be 'women' or considered feminine. It is difficult, if not impossible, for them to be both.

3.2 This attitude was articulated by one of the male coaches of the Jesters. Coming from training elite men's teams, he found the lack of fitness and skills inherent in the Jesters frustrating. But more difficult for him was the reluctance of some players to actually play rugby 'properly' - like men. The Jesters were not given any quarter in terms of tackling drills, skills or running. They were expected to do all of these things in the same way the men did. Reluctance to do so was explained by their gender. Thus, in order for the team to gain the respect and continuing attentions of the coach, they were expected to put aside their gender and be 'rugby players'. This points to the apparent contradiction between being both a woman and a rugby player. It is, after all, difficult to imagine a coach saying to a male team 'You're not men; you're rugby players!' In that instance, the two identities are synonymous. It is only in the example of women that an apparent contradiction exists.

3.3 This is also communicated by male players when discussing women playing rugby. Michael, a player on the first fifteen, comments that women's rugby is

a different game. Women aren't ... physically they're a different species.

Women do not play 'real' rugby and are therefore not real rugby players. However, if they do play real rugby, then they are not 'real' women.

3.4 This is a view contradicted by the Jesters, who have internalised successfully the identity of 'rugby players'. As Trish, one of the senior members of the team comments:

We are rugby players. We're ... part of the team, we play rugby and we're in the second division. l'd say, yeah, we are. We're not just playing at it, we're being it.

3.5 Because they play the sport in the same way as men, they train, socialise together and have enjoyed some success as a team, their identities as rugby players are assured. The Jesters, therefore are the identity - they are not simply pretending. The performance of this identity is therefore 'real', making the identity itself real (Butler 1997: 402). The internalisation of this identity undermines to some extent Goffman's conception of identity and the existence of a self which consciously or unconsciously performs an appropriate identity (Goffman 1990: 30). A conscious performance of a rugby playing identity would result in a different answer given by Trish. But over time, as the Jesters began to enjoy some success, they have begun to claim the identity for their own, resulting in some interesting developments in terms of their other identities, particularly in relation to the conflict between this identity and their gender.

\section{Bordertown: a gendered community}

4.1 In common with similar communities, Bordertown is characterised by strict norms governing behaviour, particularly around appropriate gender roles and sexual behaviour (Whitehead 1976; Middleton 1986; Wight 1993). Social life in Bordertown for young women and men of all ages revolves around the numerous pubs and hotels in the town. Such settings are male-dominated and women are not a visible presence. A woman without a male chaperone is assumed to be sexually available, finding herself the subject of sexual banter, innuendo, unwanted advances or physical contact. Within this context, the unchaperoned Jesters were a highly visible and potentially disruptive group:

However, we do have a bit of a reputation for drinking and ... things like that.... We weren't causing any harm to anybody. All we were doing was enjoying ourselves. But I think that Bordertown just got a shock that there was these twenty, twenty five girls ... all of a sudden out on the town all of the time. (Bethany)

4.2 Such a visible group of women attracted disapproval from some of the men because of their performance of behaviours associated with rugby. An important part of rugby sub-culture is the performance of a loud and boisterous public presence, including conspicuous alcohol consumption and the degradation of peers and strangers alike (Dunning 1986: 83), behaviours adopted enthusiastically by the Jesters. In 
behaving this way, the Jesters asserted their membership of a dominant cultural identity, but also exposed themselves to marginalisation as they became conspicuously different to other women. From the perspective of male players, such behaviour establishes the Jesters as masculine:

They're more ... manly than other women ... They're rugby players, they tend to do similar things to men off the pitch, the drinking and the singing, things like that. Whereas I don't think you'd find many groups of, you know, lady shoppers, singing or drinking pints or whatever. (Michael)

The Jesters, although behaving appropriately for rugby players, cannot also be 'ladies'. Instead, they are 'manly' women, a category not endorsed or rewarded by dominant gender norms.

4.3 The disruption caused by the Jesters' behaviour is managed through attacks on their sexuality. Players are labelled 'lesbian' if their behaviour does not conform to existing feminine norms in Bordertown. This label is particularly effective because it sexualises and objectifies the women involved. Thus, the women are seen as masculine, as lesbian, but are still ultimately subject to the male sexual gaze. This label is used both by people outside the team and within it.

4.4 The issue of problematic sexual identity is usually raised through use of the term 'butch'. This term has arisen out of an historical context associating lesbianism with masculinity (Halberstam, 1998: 119; Hargreaves, 1994: 261). Within the context of lesbian subculture, Halberstam argues that 'butches' tend to see themselves as someone 'other than a woman-identified woman' (Halberstam, 1998: 120). That is, as women who do not consider themselves women, and who may or may not be attracted to other women. In the context of Bordertown it was used to describe a woman of masculine appearance and (presumed) lesbian sexuality.

4.5 When asked about what they did not like about rugby (apart from the physical pain), six of the seven Jesters interviewed identified the lesbian or butch image of the team. Responses ranged from awareness that it represented a way of controlling their image to the fact that it did not represent how they saw themselves:

The only thing I dinnae like is all the ... lesbians in the game ... You want to see them at the Internationals. It's full of lesbians. I dinnae like that cause you're playing rugby, which is a man's sport, you get classed ... as being the same ... and I don't think that's very right. Just because you want to play a game, you're classed as being a lesbian.... Think you're all hard and butch and that ... Well ... (looking down at herself ) I wouldn't say l'm very butch like! ... You're not classed a lady or a woman when you play rugby. (Emily)

4.6 Lesbianism is problematic because of its association with masculinity. This label is recognised as a means of controlling their behaviour and causes confusion for some players:

When you say, 'I'm a female rugby player' you automatically get labelled as gay and big and butch (laughter), and it's not nice when you're at school. I'm at school and they all think I'm the big butch lass and I'm the one not to mess with. When I go to rugby, I'm the girlie girlie one. It's like I'm two different people... They say 'Oh this is Belinda ... she plays rugby'. And then they go 'Oh', like that. Because you must be gay and big and fat and butch. And I don't like that. (Belinda)

4.7 Belinda's problem is that she, like the others, does not consider herself 'one of the big, butch ones' on the team. Indeed, none of the women I interviewed identified themselves in that way. The split between the two identities Belinda feels, when she says she feels 'like two different people', is such that it becomes impossible to reconcile the two.

4.8 Rich's analysis of femininity and compulsory heterosexuality is useful in terms of explaining the subsequent behaviour of the Jesters. She argues that

[H]owever woman-to-woman relationships, female support networks, a female and feminist value system, are relied on and cherished, indoctrination in male credibility and status can still create synapses in thought, denials of feeling, wishful thinking, a profound sexual and intellectual confusion. (Rich 1980: 646)

4.9 As the male gaze remains imperative, women's behaviour and focus remains on catering to heterosexual and masculinist norms and interests. Thus concerns over the ways in which the men perceive the Jesters are of primary importance, rather than the ways the women see themselves and are prepared to interact with each other. Normality is therefore constructed by and through the male sexual gaze, presenting heterosexuality and traditional femininity as the most obvious choices for the Jesters. 
4.10 Bethany recognises that this is a problem for the team. This is articulated by the masculine, 'butch' lesbian image is one of the main problems for the team and the subsequent collapse of gender and sexuality. Such a collapse makes it very difficult for the team to ever win acceptance from some members of the community:

You know, I don't think they like the lesbian . . . side, at all. I think if it was somebody who was very feminine, they'd think it was good, but when they're not, they don't like it. (Bethany)

4.11 This implies a further problem. Although lesbianism is associated with un-feminine, and therefore inappropriate behaviour, it also objectifies the women. Lesbian sexual activity between two 'feminine' (or heterosexually attractive) players would be seen as 'good' by observing men. For example, Michael claims that women's rugby does not interest him:

Unless I maybe coach the English lesbian rugby or something! (Laughter).

4.12 His involvement in women's rugby would be aimed at satisfying his sexual desires, regardless of the players' orientations. He assumes that women would be playing for his gratification. This objectification is pervasive. Bethany complains that the immediate reaction of men upon finding out that she plays rugby is sexual:

'Phwoar, what are you like down in the scrum, you touch each other up?'

Women are asked if they have sex in the showers, and stories are told by men of visiting women's rugby teams whose members were couples. The entire context of women's rugby is sexualised as a result.

4.13 This objectification is maintained throughout all of the discussions with the women and men. Kieran, for example, when talking about women who played rugby was presented with the scenario of his meeting a very attractive, feminine looking girl who happened to play rugby:

It would maybe be a one night stand or something but (Laughter), it wouldn't be ... a relationship!

4.14 Again, this woman is an object for his sexual gratification - she is not someone with whom he would consider having a serious relationship, but an object to be used and discarded. Once a woman starts to play rugby, she loses any claims to respectability. She must either be lesbian or sexually available to men. Thus, for men, the Jesters are a source of ambivalence: they are noisy and feminine, objects of sexual desire and heterosexually unavailable. Despite this, as we can see, the women continue to be constructed as sexual objects. This results in intense efforts to control and perform these acceptable identities.

\section{Strategies for self-control}

5.1 The strategies employed by the Jesters to assert control over their 'self' image are similar to those outlined by Lenskyj (Lenskyj 1994), Kolnes (Kolnes 1995) and Cox and Thompson (Cox and Thompson 2000). They include the maintenance of an atmosphere of compulsory heterosexuality, and on-going attention to appearance and apparent sexual availability. The construction of such behaviour as a 'strategy' implies that the resulting performance is a consequence of conscious calculation on the part of the Jesters. This certainly appears to be true. Without this performance, the Jesters would face serious social censure and exclusion (Butler 1997: 405). These behaviours represent strategies for survival. However, they also represent an internalised identity for the Jesters - that is, they have come to reflect the 'normal' within the team.

5.2 Such behaviour reinforces Butler's analysis of the role of performance in enforcing gender norms and beliefs. Butler argues that

Significantly, if gender is instituted through acts which are internally discontinuous, then the appearance of substance is precisely that, a constructed identity, a performative accomplishment which the mundane social audience including the actors themselves come to believe and to perform in the mode of belief. (Butler 1997: 402)

5.3 This indicates that gender is not an inherent belief, but is rather an identity constituted in performance. However, it is through that performance that the identity becomes 'real' or normal. Thus, in performing a particular type of identity - that of heterosexual hyper-femininity - the Jesters come to reinforce that norm, which encloses them in the cycle in which they find themselves. By accepting the construction of femininity established by the men involved, and by performing the preferred gender norm, the existing normality remains unchallenged. 
5.4 It is interesting to note that the Jesters do make explicit efforts to control the ways in which they are perceived, and to perform an acceptable or 'normal' identity. It is particularly interesting to note that this occurs both in private and in public with the team. That is, the performance of the gender norms is not simply a conscious performance for the benefit of observers, but instead represents an internalisation of these standards by the Jesters themselves. This is shown in the public and private behaviour of the Jesters, particularly around attention to appearance, public performances of heterosexuality of an acceptable kind, and the attempts to de-sexualise all areas of interaction between the Jesters themselves, including the changing rooms.

5.5 In public, the majority of the Jesters made explicit efforts to conform to heterosexual ideals of attractiveness and femininity. Thus, concern was expressed when their appearance was interpreted in terms of their participation in rugby:

[W]e were talking about clothes or something and she goes 'And obviously you wear trackies all the time because ...you're sporty...I wear this because I'm not sporty.' and I thought to myself, I'm sick of people thinking that I'm this sports freak, because if I could fit into my bloody jeans, l'd wear them!... So she was a good mate of mine, and I was a bit 'Oh God, does everyone think that I dress like a man?' (Bethany)

Bethany was one of the most concerned players about her appearance. She regularly wore skirts or dresses out, brought along her hair drier to games, and usually wore make-up. She also grew her hair long, in an effort to combat such perceptions.

5.6 The effect of the perceptions was reinforced by the perceptions of female players by male players. These views were characterised by a perceived androgyny of women involved in rugby, and an ambiguity about the position played. The following is a combination of male views:

They are big girls, fattish, plump, solid, you know, they're ... similar sort of build I would expect [to the men], to be honest. ... maybe not as muscular because I don't think women would go out of their way to make themselves ... maybe some of them do. Short hair. I don't know about their fitness because I don't really see a lot of them play ... But ... they all seem to be about the same size.

5.7 This is significant because such a description is at odds with the description given of male players, where diversity of physiques is considered normal. Back line players are smaller than the forwards, and different positions take on different roles. Women, on the other hand, seem to be cut out of the same mould - they are square, solid, with short hair. There are no distinguishing features either between the players themselves or to mark them as female. Such a view ignores the real diversity of physical shapes and sizes within the Jesters but represents a norm which the Jesters must combat.

5.8 This was done, not only through care of appearance, but also by the performance of a 'normal' or appropriate sexuality. Thus sexual behaviour is a 'public' concern and so is monitored. Team members are encouraged to establish themselves as visibly heterosexual but not being 'easy'. Team-mates made it clear that casual sex was not openly acknowledged or encouraged and that 'nice girls' 'made love' rather than had sex. This was reinforced by the team's characterisation of a former member as a 'slut' because she had 'been with' several members of the men's team. However, the practice of getting a 'click' (having casual sex, or a one night stand) was part of the culture of touring and team nights out away from Bordertown. Thus, a public face of 'normal' or acceptable heterosexuality was established (Gill and Maclean 2002).

5.9 This was a marked contrast to the expression of lesbian sexuality. In this context, players were 'allowed' to be lesbian as long as this was not publicly performed. Thus, when lesbian team members were out with the team, they were also expected to participate in the heterosexual or asexual team performance. Their partners were denied access to team events and were not acknowledged socially by the Jesters as a collective, resulting in intense distress to the players involved. Although aware of this distress, the Jesters persisted in ignoring the sexuality and personal lives of some of the players and failure to conform to such norms resulted in social isolation from the team.

5.10 Although some of this could be read as a conscious or cynical performance, the extent to which it supports Butler's thesis regarding the development of norms through behaviour is obvious (Butler 1997: 411). The internalisation and normalisation of heterosexual norms is best displayed by an analysis of the Jesters' behaviour when away from public scrutiny, such as in the rituals surrounding the showers and changing rooms. Behaviour in these areas was strictly controlled. For example, some players refused to shower with anyone suspected of being or known to be lesbian. Thus, the team used the changing rooms and showers in a strict order, with lesbian players waiting outside, while these players shower and get dressed. After an interval, lesbian players entered while unworried players changed and showered. Finally, 
the lesbian players showered. Although this was never discussed, the order rarely varied, and players wishing to change their place, for example to leave early, asked permission from the rest of the team. One player always showered alone and as a result, either found an alternative shower or showered last, waiting for everyone else either in the bar, or in the changing rooms as everyone else gets changed, her discomfort surrounding her own body not extending to the sight of other naked bodies.

5.11 Eye direction and observation was also controlled. Players did not look at each other in the changing rooms, preferring to converse while looking at the wall or the floor. Inevitably, everyone's body was on display, but direct glances and eye contact were not encouraged. When dressing, it was normal to keep the body covered with a towel as much as possible. In the showers, people were reluctant to use the showers next to each other, leaving spaces wherever possible. Comments about others' bodies were allowed, but only when both players were clothed. In such instances, discussions about tattoos, weight loss or body image were normal. The only variation concerned injuries to arms, legs, back or face sustained during the game. In these instances, the comments were usually made as a joke, generally about the players' sexually 'deviant' behaviour. These techniques assisted the Jesters in developing a heterosexual team identity and distancing themselves from accusations of lesbianism. This resulted in a consciously and unconsciously homophobic atmosphere on the team, where players are careful to perform an acceptable sexuality, or hide a potentially unacceptable one. Failure to conform to such norms results in social isolation from the team.

\section{Consequences of identity management}

6.1 As discussed above, the Jesters struggle to control the public face of the team by performing a hyperfeminine, explicitly heterosexual 'face' in public at least. Such a strategy prevents the marginalisation of most team members from mainstream Bordertown society, enabling their continued integration. However, for some team members, such a performance results in a double marginalisation and an alienation from what they consider to be their own sexual identity.

6.2 For lesbian members of the Jesters, the performance of a heterosexual identity results in their alienation from the majority of the team. Although their sexuality is something of an open secret both within the team and the broader community, nonetheless, they are expected to 'perform' an 'acceptable', 'unproblematic' and 'normal' sexual identity whenever they are associated with the rest of the team. The expectations of such a performance cause resentment and unhappiness, yet so does the continued marginalisation experienced despite efforts to conform. This section explores the way in which 'normal' is negotiated within the team. It is perhaps the ultimate irony that a group of women who are consciously participating in an activity which threatens to disrupt gender norms are also willing and able to marginalise their own team members.

6.3 This issue of normalising femininities emerged only gradually over the course of the fieldwork, and it is indicative of my own initial status as an outsider and radically different upbringing that the issue of lesbianism as a challenging or problematic femininity was not immediately apparent. In fact, it was only over the course of the two and a half years spent in the field that issues of sexuality became apparent and problematic.

6.4 One of the main attractions of playing rugby for many of the women is the level of social support and integration their involvement allows. The team itself emphasises the importance of supporting fellow team members, both on the pitch and off:

[W]e've got a team spirit, you know what I mean? You can go, even if you're not playing, you can guarantee that somebody will speak to you or give you a phone, that sort of thing. (Ciara)

I was going to say when we go out we don't take over but we do! But ... we're just enjoying ourselves, it's not to ... get people's backs up or anything like that. It's just because we're a team. We just want to enjoy ourselves. (Trish)

I ... love the team. I think it's amazing you know? I really do. It's like having 20 sisters. It's really quite cool ... and I enjoy it. I love the tours and I do enjoy all that. That's why it's important to us. (Bethany)

These positive affirmations of team spirit and mutual support must be contrasted with the exclusion suffered by the lesbian team members.

6.5 This exclusion occurred progressively, mirroring the gradual 'coming out' of team members and the efforts of the Jesters to control this process. Initially, accusations of lesbianism within the team were unproblematic. As Bethany said: 
I used to say 'We don't have any lesbians on our team.'...Which was true. Well, I thought it was, until last year, and now I can't say that any more ... So now I have to say 'Yeah, we've got lesbians on the team, but there's only three ... And I am not a lesbian.' It doesn't bother me because I've never ever been asked if I was a lesbian. I think it's cause I'm one of the more feminine ones. Long hair and the skirts ...

6.6 With three players openly lesbian, the remainder of the Jesters were confronted with the possibility of either their own or other team members' 'hidden' abnormality. This resulted in efforts to establish themselves and the team as 'normal'. As the number of lesbian players increased, the capacity of the Jesters to manage their public face and their sense of normality decreased, resulting in the explicit exclusion of their fellow team members, in direct contradiction to the stated norms of team spirit and mutual support expressed above.

6.7 Despite increasing unease, the process of exclusion occurred over several months. In fact, I became aware of these processes over a period of a year and a half, in part because of my own ignorance of the Jesters' regular functioning. But this was also because the process itself had two distinct stages: management and expulsion; and centred on one player in particular.

6.8 Elizabeth was identified as the scape-goat for the increase in lesbianism among the Jesters. This in itself was unusual because Elizabeth was one of the senior team members and because Elizabeth's coming out did not occasion upheaval and was managed discretely. However, identifying Elizabeth as 'responsible' enabled the Jesters to utilise the narrative of seduction by an older woman of a younger one. The younger woman was therefore seduced away from her 'true' heterosexual identity by a predatory older, and embittered, woman.

6.9 Initially, it appeared that the Jesters as a whole were going to successfully absorb the emergence of lesbian players. The first players to come out, Elizabeth and Janine, managed the situation effectively. The team discovered that they were having a relationship when the Jesters were on an end of season tour. This was a good context for disclosure as players were not going to socialise for three months and the team was focused on other events, including the revelation of new relationships for other players, as well as the appearance of an Australian sociologist. 'Tour' can also be considered a context like the carnival in which interactions and social roles are inverted and "the awareness of the people's immortality is combined with the realisation that established authority and truth are relative." (Bakhtin quoted in (Stallybrass and White 1986: 6)) Considered this way, in a context where the unexpected was accepted and where normality inverted, disclosures regarding sexuality could be managed in the same way as other forms of sexual indiscretions and infidelities. Furthermore, both players were well known to the Jesters, and were keeping it 'in house' so to speak. No outsiders were involved.

6.10 The management strategies began here to emerge, enabling both Janine and Elizabeth to remain within the team structure. Elizabeth and Janine showered last, away from the rest of the team. They did not display affection in public, and were generally circumspect about their relationship. Elizabeth told me this was because 'they didn't want to upset the others'. This consideration resulted initially in tolerance rather than full acceptance. The two were habitually called 'the dykes' and were considered to be a separate unit within the team. However, Elizabeth observed that people began asking her questions about the relationship, although it took nearly twelve months for this to happen. Acceptance, then, was a possibility.

6.11 This situation changed half way through the following season. At this stage, I discovered that my own sexuality was the subject of scrutiny (Gill and Maclean 2002: 2.11). This enabled the exploration of some issues around lesbianism and normality within the team. Within the space of three weeks, the team's strategy shifted from management to exclusion. The data here presented is based on fieldnotes taken at the time which were analysed in conjunction with interview data collected previously and subsequently.

6.12 Ironically, it was at this stage that issues of sexuality were being discussed openly and Melinda came out, an event which was the catalyst for a team split and the total exclusion of Elizabeth. It is unclear whether this was because of the way in which it was managed by the player herself, or because the presence of three lesbians on the team was deemed to 'tip the balance' of abnormality too far. There were three main causes of upset. The disclosure was poorly managed; the player substantially altered her private (within team) behaviour prior to the disclosure; and the introduction of her partner caused the player to withdraw from contact with her team mates, something Elizabeth and Janine were careful to avoid.

6.13 Melinda was the youngest member of the Jesters, and one of those who was protected most fiercely by them. Although a strong player, she suffered from shyness, not feeling comfortable talking to large numbers of people or to new acquaintances. She was also self conscious about her body, refusing to shower with other team members. This was constructed as being a product of her age and experience relative to other team members. Furthermore her reluctance to disrobe in front of others was not unique in 
the Jesters. Melinda was well integrated into their social network. She had a particularly close relationship with Janine and Elizabeth. In addition she greatly admired Emily, who was widely acknowledged to be the Jesters' best player.

6.14 Melinda did not explicitly come out to her team mates. Rather, she was seen holding hands and kissing another woman in public. Emily was told separately by a woman not connected to the Jesters and then confronted by Melinda who told her what was going on. This caused upset on several levels. The Jesters in general were offended that they weren't told explicitly what was going on. Nor were they introduced to Melinda's partner, on the night or subsequently. Emily was upset because she felt betrayed and also because she had been told by Melinda, feeling singled out and victimised.

6.15 The mixed feelings in the team were compounded by the revelation that the relationship was of some months standing. Prior to the disclosure, Melinda had started showering with the team. Some players felt this added a sexual gaze to the privacy of the changing rooms without their knowledge, although others felt this reflected 'paranoia'. Regardless of the situation, the major emotion in the Jesters was that of betrayal and confrontation.

6.16 This confrontation was taken to a new level the following week, when Melinda's partner travelled with the team to an away game. On this trip, Melinda did not socialise with the team. Nor was her partner introduced. This was a marked contrast to the behaviour of Janine and Elizabeth. Finally, Melinda and her partner kissed and held hands openly on the team bus. Some team members complained to the captain, who reluctantly passed the complaints on. Elizabeth and Janine stepped to Melinda's defence and the resulting argument resulted in Elizabeth's ostracism from the team, and the subtle exclusion of Janine and Melinda.

6.17 Elizabeth was held responsible for the entire situation. As the older woman, she was deemed to have taken advantage of Janine's innocence. Melinda's relationship was framed in the same way: her partner was considerably older than she and was a friend of Elizabeth's. Both relationships were therefore understood as the younger players being "converted" by older women. Finally, the relationship was known to Elizabeth all along. Thus, Melinda was performing an 'abnormal' sexual identity without the knowledge of the bulk of her team mates, but with Elizabeth's knowledge.

6.18 Later that night, I was asked by Janine, in tears, whether it was 'normal' for the rest of her team members never to have seen her kiss her partner or hold her hand. Within the context of the Jesters, as I have outlined, then the behaviour was normal. This is not to defend the behaviour, but rather to highlight the extent to which 'normal' had been internalised by the Jesters as heterosexual. Fearing social repercussions, the Jesters therefore ensured that those not conforming were excluded. Ultimately this strategy was successful. Despite having registered and committed to playing, none of those three players returned to the Jesters.

\section{Conclusions}

7.1 This paper has examined some of the ways in which normality is negotiated and managed in a women's rugby team. It has been shown that normality is a social construction, which results in the exclusion of some group members. Such exclusion is necessary if the bulk of the group is to survive. However, this raises questions about the nature of femininity and gender identities more generally. Overall, it has been shown that gender identity tends to be essentialised along heterosexual lines. Thus, women are sexually available and attractive to men, not other women. The Jesters internalised this identification and version of femininity first, as Butler has argued, as a survival strategy, but then as a way of seeing themselves. Thus the performance itself has become the reality:

In opposition to theatrical or phenomenological models which take the gendered self to be prior to its acts, I will understand constituting acts not only as constituting the identity of the actor, but as constituting that identity as a compelling illusion, an act of belief. (Butler 1997: 402)

7.2 In the context of the Jesters, the act which is occurring is that of conventional heterosexual femininity. This is construed as normal. However, this normalisation is the product of external forces, in particular, the social construction of compulsory heterosexuality. Such a construction can be analysed as a means of both denying women access to club facilities because they are not 'real' rugby players, or as a means of denying them social standing because they are not 'real' or 'normal' women.

7.3 In order to overcome this 'abnormality', the Jesters internalise heterosexual femininity as normal behaviour for the team, and perform it conscientiously. In so doing, the presence of the 'abnormal' or lesbian team members represents a threat. This threat is managed by the exclusion of these team 
members, both publicly and privately. As shown in the above story, the catalyst and explanations for the team's behaviour revolve around notions of 'normality', wherein young women are seduced into an 'abnormal' way of life.

7.4 The context of the Jesters represents a stark contrast to other studies of women's sports teams. In particular, they can be contrasted with Broad's (Broad 2001: 186) study of an American women's club rugby team in the 1990s wherein:

Instead of listening to doctors, boyfriends, and family, women who played rugby continued to go out every weekend and get bruises and broken noses. Women who played rugby did not try to compensate for their non-normative behaviour by simply conforming to traditional gendered appearances. Rather than defensively curling their hair and applying make-up to apologize for their masculine athletic pursuits, rugby players resisted and challenged beauty standards through their continued participation in the sport.

7.5 The Jesters did not do this. Rather, they behaved defensively, conforming to norms imposed from the outside. This might be explained by their playing within the context of a small and fairly conservative community and with stigma in this instance may result in a loss of social standing, which may translate into a loss of opportunities for gaining partners, jobs or social interaction. Teams in larger communities may be able to develop alternative social networks. This was certainly born out in conversations with other women's rugby teams in Britain.

7.6 This paper has then questioned some assumptions about the empowering nature of women's sport. More importantly it has demonstrated the power of normalising influences on a group of women who are otherwise remarkable for their flouting of gender norms. Although prepared to risk social exclusion by participating in a men's sport, they are nonetheless not prepared to challenge all of the norms of femininity. Although unorthodox themselves, they police themselves strongly, leaving little or no room for lesbian players to exist. This has also stifled the development of other alternative femininities, including the model of feminist women, unmarried/ childless women or women who otherwise do not conform to 'normal' heterosexual femininity. The coping mechanisms within this potentially maginalised group ultimately rest on the ability of the majority to define the norm and exclude those who can not or will not conform.

\section{Notes}

1 The terms 'lesbian' and 'heterosexual' have been used throughout this paper. Neither term is understood as an 'essential' identity, but rather refer to the observed behaviours and public self-identification of the players involved.

\section{Acknowledgements}

The author wishes to thank Professor David McCrone and Dr Catherine Maclean for their invaluable supervision; the Carnegie Trust for the Universities of Scotland for two generous grants for the completion of fieldwork; the Jesters and people of Bordertown for their hospitality and understanding; and the anonymous referees whose insightful comments immeasurably improved this paper.

\section{References}

BROAD, K. L. (2001). 'The Gendered Unapologetic: Queer Resistance in Women's Sport.' Sociology of Sport Journal 18: 181 - 204.

BUTLER, J. (1990). Gender Trouble: Feminism and the Subversion of Identity . New York: Routledge.

BUTLER, J. (1997). Performative Acts and Gender Constitution: An Essay in Phenomenology and Feminist Theory. Writing on the Body: Female Embodiment and Feminist Theory. K. Conboy, N. Medina and S. Stanburg. New York: Columbia University Press: 401-417.

CAHN, S. K. (1994). Coming On Strong: Gender and Sexuality in Twentieth-Century Women's Sport . Toronto: The Free Press.

CAUDWELL, J. (1999). ' Women's Football in the United Kingdom: Theorizing Gender and Unpacking the Butch Lesbian Image.' Journal of Sport \& Social Issues 23: 390 - 402.

CHANDLER, T. J. L. (1996). The Structuring of Manliness and the Development of Rugby Football at the 
Public Schools and Oxbridge. Making Men: Rugby and Masculine Identity . J. Nauright and T. J. L. Chandler. London: Frank Cass \& Co. Ltd.

COX, B. and S. Thompson (2000). 'Multiple Bodies: Sportswomen, Soccer and Sexuality.' International Review for the Sociology of Sport 35: 5 - 20.

DUNNING, E. (1986). 'Sport as a Male Preserve: Notes on the Social Sources of Masculine Identity and its Transformations.' Theory, Culture \& Society 3.

DUNNING, E. (1999). Sport Matters: Sociological studies of sport, violence and civilization . London: Routledge.

GILL, F. and C. Maclean (2002). 'Knowing your place: Gender and reflexivity in two ethnographies.' Sociological Research Online 7(2).

GOFFMAN, E. (1990). The Presentation of Self in Everyday Life . London: Penguin Books.

HACKING, I. (1990). The Taming of Choice. Cambridge: Cambridge University Press.

HARGREAVES, J. (1994). Sporting Females: Critical issues in the history and sociology of women's sports. London: Routledge.

HILL, T. (1999). 'Wrestling with Identities: Physical Prowess and Cultural Expression.' Culture, Sport, Society 2: 108 - 126.

IRWIN, J. Thursday November 112002 'What makes a PhD student who looks like this want to fight for Cambridge?' Daily Mail London 3

JENKINS, R. (1999). Social Identity. London: Routledge.

KANE, M. J. and L. J. Disch (1993). 'Sexual Violence and the Reproductions of Male Power in the Locker Room: The "Lisa Olsen Incident".' Sociology of Sport Journal 10: 331 - 347.

KLEIN, A. M. (1993). Little Big Men: Bodybuilding Subculture and Gender Construction . Albany: State University of New York Press.

KOLNES, L.-J. (1995). 'Heterosexuality as an Organizing Principle in Women's Sport.' International Review for the Sociology of Sport 30: 61 - 77.

LENSKYJ, H. J. (1994). 'Sexuality and Femininity in Sports Contexts: Issues and Alternatives.' Jounral of Sport and Social Issues 18(4): 356 - 376.

MACLEAN, M. (2000). 'Football as a Social Critique: Protest Movements, Rugby and History in Aotearoa, New Zealand.' International Journal of the History of Sport 17: 255-277.

MANSFIELD, A., \& McGinn, B. (1993). Pumping Irony. Body Matters. D. Morgan and S. Scott. London: Falmer Press.

MIDDLETON, A. (1986). Marking boundaries: Men's space and women's space in a Yorkshire village. Deprivation and Welfare in Rural Areas. T. Bradley, P. Lowe and S. Wright. Norwich: Geo Books.

MORRELL, R. (1996). Forging a Ruling Race: Rugby and White Masculinity in Colonial Natal, c. 1870 1910. Making Men: Rugby and Masculine Identity. J. Nauright and T. J. L. Chandler. London: Frank Cass: $91-120$.

RICH, A. (1980). 'Compulsory Heterosexuality and Lesbian Existence.' Signs: Journal of Women in Culture and Society 5(4): 631-660.

RUSSELL, D. (1997). Football and the English: A Social History of Association Football in England, 1863 - 1995. Preston: Carnegie Publishing.

SABO, D. F., \& Panepinto, J. (1990). Football Ritual and the Social Reproduction of Masculinity. Sport, Men and the Gender Order: Critical Feminist Perspectives. M. M. D. F. Sabo. Champaign: Human Kinetics.

SEGAL, L. (1990). Slow Motion: Changing Masculinities, Changing Men. London: Virago Press Limited. STALLYBRASS, P. and A. White (1986). The Politics and Poetics of Transgression . London: Methuen. 
VINCENT, G. T. (1998). 'Practical Imperialism: The Anglo-Welsh Rugby Tour of New Zealand, 1908.' The International Journal of the History of Sport 15(1): 123-140.

WHITEHEAD, A. (1976). Sexual Antagonism in Herefordshire. Dependence and Exploitation in Work and Marriage. D. L. Barker and S. Allen. London: Longman.

WIGHT, D. (1993). Workers Not Wasters: Masculine Respectability, Consumption and Unemployment in Central Scotland: A Community Study. Edinburgh: Edinburgh University Press. 